stomatal number were obtained from many species that were unsuited to the 'peeling' method.

c. NoRTH

Scottish Horticultural Research Institute, Mylnefield, Invergowrie, by Dundee. Sept. 7.

${ }_{2}^{2}$ Buscalioni, L., and Pollacci, G., Atti. Inst. Bot. Univ. Pavia, 2, 83 (1902).

${ }^{2}$ Long, F, and Clements, F. E., Amer. J. Bot., 21, 7 (1934).

sennett, S. H., and Furmidge, C. G. L., Nature, 178, 152 (1956).

\section{Possible Use of Sorbic Acid as a Preserva- tive for Corn Silage}

MANy types of preservatives such as ground cereals, sugar beet pulp and molasses are employed to preserve silage in the best possible condition. These preservatives are high in fermentable carbohydrates which help to stimulate lactic acid fermentation. Some farmers have been using hydrochloric and sulphuric acids to control the protein breakdown which gives an unpleasant smell to silage. The use of ground cereals is uneconomical. Beet pulp and molasses are available only in certain places and usually in limited supply. Inorganic acids like hydrochloric or sulphuric are strong acids, and, from the point of view of farmers, they have been difficult to handle and distribute in the silo. Likewise, such acids produce deleterious effects on the digestive system of farm animals. Virtanen ${ }^{1}$ reported that there is a need for a suitable and cheap organic acid for silagemaking with acids.

In recent years sorbic acid, a mild organic acid, has been used extensively as a fungistatic agent in the food-processing industries. In cucumber fermentation, $0 \cdot 1$ per cent sorbic acid controlled yeast scum formation without interfering with the normal and desired fermentation by bacteria which produces lactic acid ${ }^{2}$. It has also been shown that the sorbic acid is less toxic and a better preservative than sodium benzoate ${ }^{3,4}$.

Wide-mouth glass jars were used as the experimental silos. The corn silage was prepared in them as it would have been in the regular silos. Prior to ensilage, corn plants were chopped into small pieces and were 'pitched' in the 'silos'. Each layer was packed well. Water was sprinkled on the top of each layer in the case of untreated (control) silos which were again packed to remove the air pockets. In the case of treated silos, sorbic acid solutions were sprinkled instead of water. Concentrations of $0 \cdot 3$, $0 \cdot 2,0 \cdot 1,0 \cdot 05$ and 0.025 per cent of sorbic acid on an absolute weight basis were prepared in tap-water and were sprinkled on the top of each layer of the ensilage material. Sorbic acid was kindly furnished by the Carbide and Carbon Chemicals Co., New York. Some of the silos thus prepared were covered with air-tight lids and the remainder were uncovered. The experiment was conducted in triplicate. Following ensilage and treatments, the silos were stored in cardboard boxes at room temperature for a period of five months. After five months, they were weighed to determine the percentage loss in weight and were opened to inspect the microbial growth on the surface.

It was noticed that the silage was less affected by mould than untreated silage. Higher concentrations of sorbic acid were more effective in con-

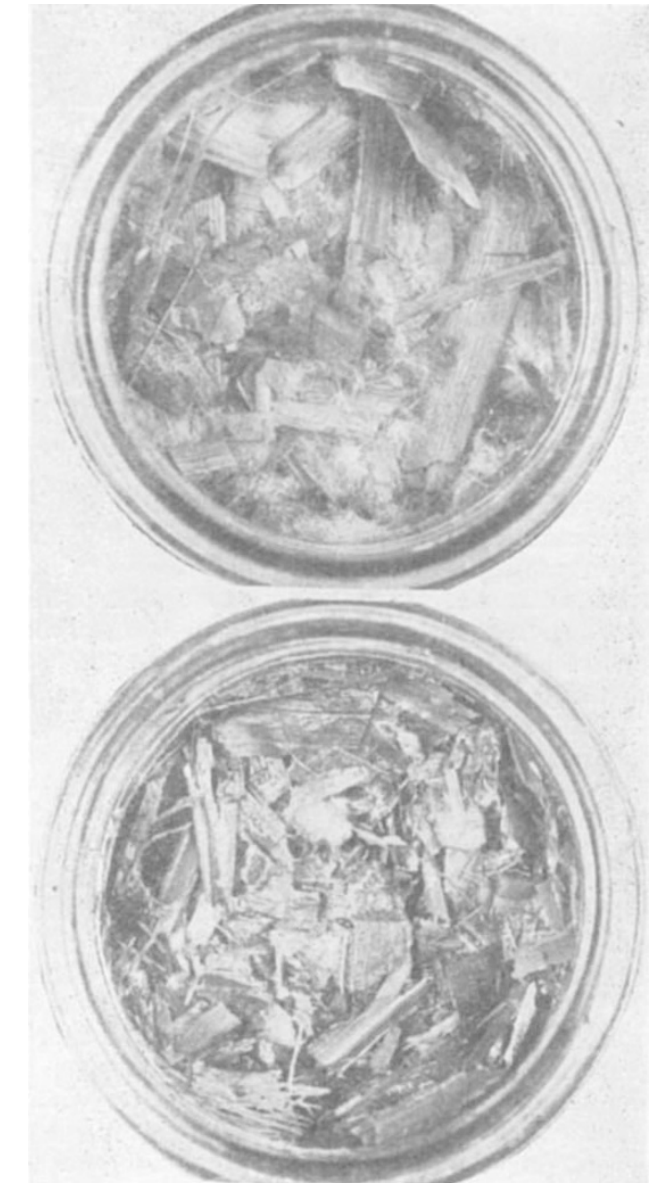

Fig. 1. Top, Growth of mould in profusion on the surface of on the surface of silage sprinkled with $0 \cdot 1$ per cent sorbic acid solution

trolling the mouldy growth than the lower concentrations. However, the concentration 0.1 per cent was quite as effective as that of 0.3 per cent.

Fig. 1 (top) shows the profused growth of mould on the top layer of the silo which was sprinkled with water and Fig. I (bottom) shows very little or no growth on the top layer of the silo which was sprinkled with sorbic acid solution at the concentration of 0.1 per cent. Mouldy growth on the silage gives bad odour and flavour.

The occasional spraying of the silage material with harmless sorbic acid solution $(0 \cdot 1$ per cent) while the silo is being filled will preserve silage in good physical condition. At the same time a larger percentage of proteins will be preserved which ultimately will be recovered in milk and in meat. The $p H$ of sorbic acid $(0 \cdot 1$ per cent) solution is $3 \cdot 6$. The preservation of the silage material at such low $p \mathrm{H}$ produces silage of high quality.

Department of Horticulture,

Utah State Agricultural College, Logan, Utah.

1 Virtanen, A. I., Proc. 6th Int. Grassland Cong., 2, 1147 (1952).

2 Phillips, G. F., and Mundt, J. O., Food Technol., 4 (7), 291 (1950).

${ }^{3}$ Deuel, jun., H. J., Alfin-Slater, R., Weil, C. S., and Smith, jun., H. F. Food Res., 19 (1), 1 (1954).

4 Salunkhe, D. K., Food Technol., 9 (11), 590 (1955). 